\title{
INFLUENCE OF NaCL SALINITY ON GERMINATION AND EARLY SEEDLING GROWTH IN WHEAT (Triticum aestivum,
} L.).

Helaly, M.N.*; Z.A. Mohamed*; M.M. Abdel Maksoud ${ }^{* *}$ and Sally A. A. Arafa*

* Dept. of Agric. Botany, Faculty of Agric., Mansoura Univ., Egypt.

** Dept. of Genetic, Faculty of Agric.. Mansoura Univ., Egypt.

\begin{abstract}
Some wheat genotypes were evaluated to salt stress during the germination and early seedling growth. Salinity, in general decreased germination percentage and seedling growth characters representing by root and shoot lengths as well as their fresh and dry weight in most studied genotypes depending on the genotypes and the level of $\mathrm{NaCl}$ salinity . however, genotypes Gemmeiza 7 and Gemmeiza 10 x C.B.255 showed a stimulation response to $\mathrm{NaCl}$ salinity up to $6000 \mathrm{mg} / \mathrm{l}$. The stimulating effect of salinity on the two mentioned genotypes was discussed.

On the other hand, total sugars and proline concentrations were significantly increased in the shoots of all genotypes grown under salt stress. Moreover, $\mathrm{Na}^{+}$ concentration was increased whereas, that of $\mathrm{K}^{+}$decreased in the shoots.

The data concluded that, cv(s) Gemmeiza 7 and Gemmeiza 10x C.B.255 of wheat were more tolerant to salt stress up to $6000 \mathrm{mg} \mathrm{NaCl} / \mathrm{l}$ and the former $\mathrm{cv}$ proved to be more tolerant as compared to all studied genotypes.

Keywords: Wheat, salinity, germination, seedling growth.
\end{abstract}

\section{INTRODUCTION}

Wheat (Triticum aestivum, L. Poaceae) is one of the most important cereal crops in Egypt. Its production is still insufficient to overcome the consumption demand due to the limited area and restricted resources of the fresh water. Salinity is one of the main limiting factor for its cultivation, seedling growth and productivity. The common approach in breeding for salt stress tolerance is to select for its components. Breeders assume that, there is considerable variability in abiotic stress tolerance in wheat germplasm. It is closely related characteristics that influenced by genetic (Varietals), environmental conditions, seed processing, physiological treatment effects and others (Helay et al., 2009-b). However, several of these components are difficult to measure, indirect selection showed be applied (Visser, 1994).

Studied on abiotic stress (salinity and drought) tolerance in wheat have been undertaken for the identification of environmental and physiological factors. Germination percentage of wheat measured under standard conditions correlated with the seedling establishment in the field under stress condition (Sadeghian and Yavari,2004). Unfavourable germinations such as salinity have serious impacts on the results of vigour tests and plant establishment of wheat and delayed seedling emergence. Small differences in the $\mathrm{NaCl}$ levels did not change number of germinated grains but greatly affected water uptake and seedling growth (Bray, 2000). 
Helaly, M.N. et al.

Sadeghian and Yavari (2004) reported a similar germination rate for primed saline and primed seeds in plots with low salinity level. This practice is certain to become a seed enhancing requirement for crop production under stressed conditions. Tugnoli and Bettin (2001) found that, productivity and germination are linked to key properties of varieties used and tend to decide the ultimate crop yield. Several investigators (Sadeghian and Yavari,2004 ; Helaly et al., 2009-b) found that, seed germination and early seedling growth are the stages most sensitive to salt stress.

On the other hand, breeding programs should be explicitly direct towards development of salt -tolerant varieties due to tissue culture technique. Foolad et al., (2003) studied the germination response of tomato accessions in Petri dishes containing agar media treated with zero $\mathrm{mM} \mathrm{NaCl}$ (non-stress) and cold stress treatments or $150 \mathrm{mM} \mathrm{NaCl}+15 \mathrm{mM} \mathrm{CaCl}_{2}$ for salt stress treatments. They concluded that, some of the same genetic and physiological parameters contributing to rapid seed germination under nonstress conditions could also facilitate rapid seed germination under stress.

Therefore, the present investigation was performed for the evaluation of genetic trials and to gain some information on the effects of $\mathrm{NaCl}$ salinity on germination and certain morphological parameters of some wheat genotypes at the early seedling stage. These genotypes exhibiting contrasting levels of salt resistance.

\section{MATERIALS AND METHODS}

The present investigation was carried out under controlled conditions at the Labs of Department of Agric. Botany, Faculty of Agriculture, Mansoura University, Egypt during the growing season of 2007/2008.

Plant matereial:

Grains of eight wheat genotypes (Triticum aestivum, L. Poaceae) with different backgrounds were obtained from the Field Crops Research Institute, Gemmeiza Research Station, ARC, Egypt. The characteristics of these genotypes are presented in Table 1.

Germination experiment:

Grains of each genotype (8 genotypes) were surface sterilized by sooking in $0.001 \mathrm{HgCl}_{2}$ for one min., washed with distilled water and germinated between discs of filter papers (Whatman No. 1) in covered glass Petri dishes $(12 \mathrm{~cm})$. The grain beds were moistened with $10 \mathrm{ml}$ of half Hoagland strength nutrient solution ( Hewitt, 1952), supplemented with Nacl at four levels denoted 0 (control), 4000, 6000 and $8000 \mathrm{mg} / \mathrm{l}$ for each genotype. Each treatment was replicated five times (5 dishes) and each replicate contained 10 grains. The germination was took place for two weeks in darkness in an incubator at $28^{\circ} \mathrm{C}$. Germination percentage was recorded, daily, during the incubation period. The relative germination (GR)was calculated (Smith and Dobrenz, 1987) .

$G R=\frac{\text { Number of germination grains in the stressed medium } \times 100}{\text { Number of germination grains in control medium }}$ 
Table (1): The commercial name, identification characteristics and sources of the wheat (Triticum aestivum, L.) genotypes evaluated in the present investigation.

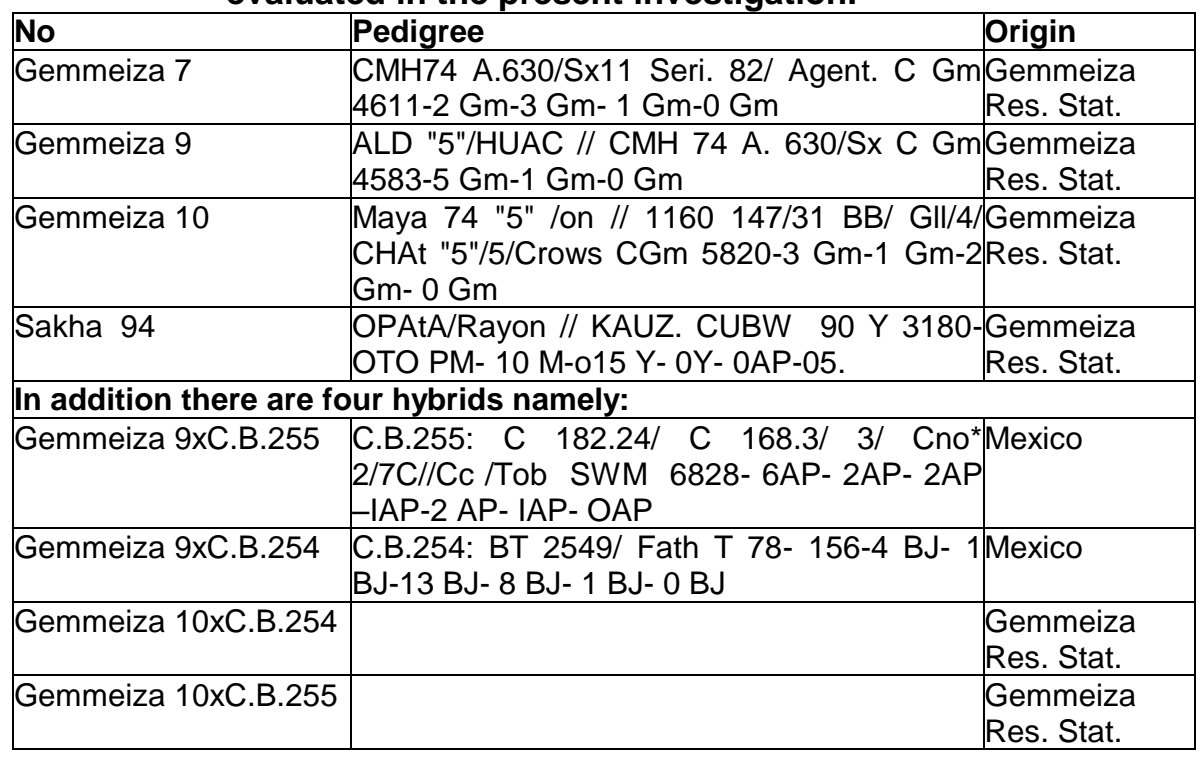

After germination, seedlings were allowed to grow for further two weeks from germination. At the end of experiment, the following characteristics were studied:

Root length $(\mathrm{cm})$, shoot length $(\mathrm{cm})$, root fresh and dry weights $(\mathrm{mg})$, shoot fresh and dry weights $(\mathrm{mg})$.

Seedlings were taken and separated into their roots and shoots. Fresh weight was immediately determined to avoid any loss of water content. Thereafter, roots and shoots were dried overnight in an electric oven at $70^{\circ} \mathrm{C}$ until a constant weight and attained.

Total sugar was estimated using the method of Sadasivam and Manikam (1996) as well as proline (Bates et al., 1973). Moreover, $50 \mathrm{mg}$ dried materials from the roots or $100 \mathrm{mg}$ from the shoots were taken for digestion in a mixture of sulphoric acid, salicylic acid and hydrogen peroxidase (Hanaa Fatouh, 2003). $\mathrm{Na}^{+}$and $\mathrm{K}^{+}$were determined by an atomic absorption Spectrophotometers (GBC, 932 AA).

\section{RESULTS AND DISCUSSION}

Decreased germination under salt stress may be measured as delaying of emergence, reduction of the ultimate germination percentage or both. Table (2) shows that, the reduction in germination percentage and the increase in time required for wheat grains to germinate due to salt stress were observed in all genotypes under investigation. However, genotypes Gemmeiza 7 and Gemmeiza 10 x C.B. 255 were more tolerant to saline condition particularly at the lowest salinity levels (4000 and $6000 \mathrm{mg} \mathrm{NaCl} / \mathrm{l})$ as compared to all other ones since they were less affected by salinity. 
Helaly, M.N. et al.

The harmful effects of salt stress on germination may be due mainly to either colloidal inhibition of water occurred by grains and /or imbalanced osmotic water uptake occurred by germinated seeds (Helaly et al., 2009-a). Moreover, altering the hormonal balances and decreasing endogenous cytokinins biosynthesis and auxin production were reported under stress by Schmidt (2005). The latter author added that, stress decreased the accumulation of reducing sugars within the plant tissues which decreased wilting resistance. Moreover, it was found that salinity stress did not induce an increase of ascorbic acid which not only quenches reactive oxygen but also regenerates $\alpha$-tocopherol (Gadalla, 2009).

The harmful effect of stress on germination and seedling growth represented by the dry matter accumulation seemed to be due to the suppression of plant metabolism under such condition (Demir et al., 2003). Salt stress adversely affect the physico-chemical properties of the protoplasm and cell membranes (Tajdoost et al., 2007). Inhibition of cytokinin biosynthesis and hormonal unbalances, reducing water content and some plant nutrients uptake as well as biosynthesis of a-tocopherol , ascorbic acid and net photosynthetic rate accompanied with high respiration rate were also reported under stress conditions (Tripathi et al., 2007).

Table (2): Effect of $\mathrm{NaCl}$ salinity on germination percentage of wheat genotypes.

\begin{tabular}{|l|c|c|c|c|c|}
\hline \multicolumn{1}{|c|}{ Salinity (mg/l) } & $\mathbf{0}$ & $\mathbf{4 0 0 0}$ & $\mathbf{6 0 0 0}$ & $\mathbf{8 0 0 0}$ & Mean \\
\hline Genotypes & 99.7 & 98.7 & 98.0 & 97.3 & 98.3 \\
\hline Gemmeiza 7 & 99.3 & 98.3 & 95.3 & 90.2 & 95.8 \\
\hline Gemmeiza 10xC.B. 255 & 98.8 & 91.5 & 86.4 & 71.5 & 87.0 \\
\hline Gemmeiza 10 & 98.6 & 95.5 & 86.6 & 75.1 & 88.9 \\
\hline Gemmeiza 9 & 98.4 & 96.6 & 86.7 & 71.9 & 88.4 \\
\hline Gemmeiza 9 x C.B. 255 & 98.3 & 96.0 & 87.7 & 78.3 & 90.1 \\
\hline Gemmeiza 9 X.B. 254 & 98.2 & 93.3 & 86.8 & 71.7 & 87.5 \\
\hline Gemmeiza 10xC.B. 254 & 98.2 & 87.1 & 77.8 & 70.3 & 83.3 \\
\hline Sakha 94 & 98.7 & 94.6 & 77.3 & 78.3 & 89.9 \\
\hline Mean & & & 0.11 & & \\
\hline LSD at 5\% for: & & & & \\
Genotypes & & & & \\
Salinity \\
Gen. x Salinity
\end{tabular}

\section{Root and shoot length of the seedlings:}

Table (3) shows that, all investigated wheat genotypes except that of Gemmeiza 10x C.B.255 showed a decrease in their root and shoot lengths of their seedlings with an increase in $\mathrm{NaCl}$ salinity levels. However, both genotypes Gemmeiza 7 and Gemmeiza 10x C.B.255 showed an increase in the length of their roots and shoots due to an increase in salinity levels up to $6000 \mathrm{mg} / \mathrm{l}$ thereafter decreased. The stimulating effects of low salinity levels (4000 and $6000 \mathrm{mg} / \mathrm{l}$ ) were previously reported by Chen and Murata (2002) on wheat plant who attributed this increase to the beneficial effects of salinity on both cell division and cell enlargement. The inhibitive effects of high salt level may be due to its effect on apical growth as well as hormonal balances within the plant tissues (Abo Shama and Hegazy, 2009) . 
Table (3): Effect of $\mathrm{NaCl}$ salinity on root and shoot length (cm) of wheat genotypes at four weeks from sowing.

\begin{tabular}{|c|c|c|c|c|c|c|c|c|c|c|}
\hline \multirow{3}{*}{$\overbrace{\text { Genotypes }}^{\text {Treatments }}$} & \multicolumn{5}{|c|}{ Root length (cm) } & \multicolumn{5}{|c|}{ Shoot length (cm) } \\
\hline & \multicolumn{10}{|c|}{ Salinity $(\mathrm{mg} / \mathrm{l})$} \\
\hline & 0 & 4000 & 6000 & 8000 & Mean & 0 & 4000 & 6000 & 8000 & Mean \\
\hline Gemmeiza 7 & 15 & 19 & 18 & 7 & 15 & 18 & 20 & 18 & 9 & 16 \\
\hline Gemmeiza 10xC.B. 255 & 16 & 17 & 19 & 8 & 15 & 18 & 19 & 20 & 11 & 17 \\
\hline Gemmeiza 10 & 17 & 15 & 10 & 5 & 12 & 15 & 16 & 12 & 8 & 13 \\
\hline Gemmeiza 9 & 18 & 16 & 9 & 6 & 12 & 20 & 18 & 12 & 8 & 14 \\
\hline Gemmeiza 9 x C.B. 255 & 16 & 15 & 13 & 12 & 14 & 18 & 16 & 13 & 14 & 15 \\
\hline Gemmeiza 9 x C.B. 254 & 18 & 16 & 13 & 12 & 15 & 15 & 12 & 9 & 8 & 11 \\
\hline Gemmeiza 10xC.B. 254 & 17 & 16 & 12 & 11 & 14 & 15 & 14 & 12 & 9 & 12 \\
\hline Sakha 94 & 17 & 15 & 13 & 12 & 14 & 16 & 12 & 11 & 9 & 12 \\
\hline Mean & 16 & 16 & 13 & 9 & 13 & 17 & 16 & 13 & 9 & 14 \\
\hline $\begin{array}{l}\text { LSD at } 5 \% \text { for: } \\
\text { Genotypes } \\
\text { Salinity } \\
\text { Gen. x Salinity }\end{array}$ & & & $\begin{array}{l}1.8 \\
1.0 \\
3.5\end{array}$ & & & & & $\begin{array}{l}1.9 \\
0.9 \\
3.7\end{array}$ & & \\
\hline
\end{tabular}

Seedlings fresh and dry weights:

Data presented in Tables (4 and 5) show that, salinity decreased fresh and dry weights of the roots and shoot systems. This reduction was found to be a concentration and genotype dependant. However, root fresh and dry weights of all investigated genotypes were decreased under Nacl salinity except that of genotypes Gemmeiza 7 and Gemmeiza 10 x C.B.255 which showed an increase at $\mathrm{NaCl}$ salinity up to $6000 \mathrm{mg} / \mathrm{l}$ thereafter decreased. The variation between the genotypes may be due to the genetic action (Esmail, 2005). The same trend was recorded for fresh and dry weight of the shoot system. In this context, Chen and Murata (2002) found that, plant growth was stimulated at the low salinity level whereas inhibited as the concentration of salinity was raised. Several investigators recorded an inhibition of growth caused by salinity due to its effects on hormonal balance (Schmidt, 2005), insufficient supply of ions or other solutes to the growing region (Gadalla, 2009), insufficient osmotic solutes to generate turgor (Hatung, 2004).

Table (4): Effect of $\mathrm{NaCl}$ salinity on shoot fresh and dry weights $(\mathrm{mg} /$ plant) of wheat genotypes at four weeks from sowing .

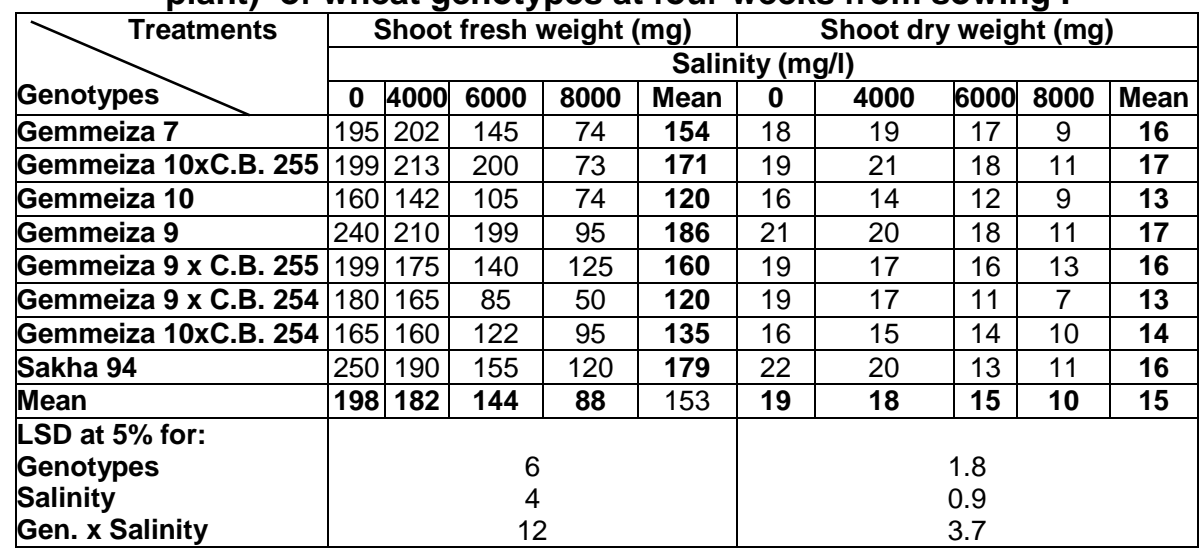


Table (5): Effect of $\mathrm{NaCl}$ salinity on root fresh and dry weights (mg/plant) of wheat genotypes at four weeks from sowing.

\begin{tabular}{|c|c|c|c|c|c|c|c|c|c|c|}
\hline \multirow{3}{*}{${ }_{\text {Genotypes }}^{\text {Salinity }(\mathrm{mg} / \mathrm{l})}$} & \multicolumn{5}{|c|}{ Root fresh weight (mg) } & \multicolumn{5}{|c|}{ Root dry weight (mg) } \\
\hline & \multicolumn{10}{|c|}{ Salinity (mg/l) } \\
\hline & 0 & 4000 & 6000 & 8000 & Mean & 0 & 4000 & 6000 & 8000 & Mean \\
\hline Gemmeiza 7 & 99 & 105 & 87 & 30 & 80 & 5.5 & 5.7 & 4.2 & 2.1 & 4.4 \\
\hline Gemmeiza 10xC.B. 255 & 100 & 115 & 120 & 50 & 96 & 6.1 & 6.5 & 7.6 & 3.9 & 6.0 \\
\hline Gemmeiza 10 & 102 & 99 & 44 & 25 & 67 & 6.8 & 6.1 & 3.5 & 2.8 & 4.8 \\
\hline Gemmeiza 9 & 120 & 101 & 86 & 54 & 90 & 7.7 & 7.5 & 4.8 & 2.8 & 5.7 \\
\hline Gemmeiza 9 x C.B. 255 & 133 & 120 & 115 & 99 & 12 & 7.9 & 7.2 & 7.0 & 6.8 & 7.2 \\
\hline Gemmeiza 9 x C.B. 254 & 105 & 95 & 42 & 18 & 65 & 6.0 & 5.1 & 3.2 & 2.0 & 4.1 \\
\hline Gemmeiza 10xC.B. 254 & 115 & 96 & 66 & 45 & 80 & 7.0 & 6.8 & 6.2 & 6.0 & 6.5 \\
\hline Sakha 94 & 136 & 120 & 77 & 56 & 97 & 7.0 & 6.1 & 4.2 & 3.1 & 5.1 \\
\hline Mean & 114 & 106 & 80 & 47 & 86 & 6.7 & 6.4 & 5.1 & 3.7 & 5.5 \\
\hline $\begin{array}{l}\text { LSD at } 5 \% \text { for: } \\
\text { Genotypes } \\
\text { Salinity } \\
\text { Gen. x Salinity }\end{array}$ & \multicolumn{5}{|c|}{6} & \multicolumn{5}{|c|}{$\begin{array}{l}0.25 \\
0.18 \\
0.50\end{array}$} \\
\hline
\end{tabular}

\section{Organic Solutes Accumulation:}

1- Free proline:

Data presented in Table (6) reveal that, proline concentration was increased in the shoots of all studied genotypes due to saline treatment up to the highest level $(8000 \mathrm{mg} \mathrm{NaCl} / \mathrm{l})$. The obtained results confirmed the welldocumented results recorded in the majority of cases that the main feature of increasing salinity concentration is the accumulation of proline in the tissues as did with sugars, it is the striking sequence of salt stress. Consequently, increasing salinity level caused an increased accumulation of proline in the tissues of stressed wheat seedling.

Table (6): Effect of $\mathrm{NaCl}$ salinity on proline concentration (mg/g F.Wt.) in the shoots of wheat genotypes at four weeks from sowing.

\begin{tabular}{|l|c|c|c|}
\hline \multicolumn{1}{|c|}{ Salinity (mg/l) } & $\mathbf{0}$ & $\mathbf{8 0 0 0}$ & Mean \\
\hline Genotypes & 11.583 & 17.353 & $\mathbf{1 4 . 4 6 8}$ \\
\hline Gemmeiza 7 & 6.200 & 10.373 & $\mathbf{8 . 2 8 7}$ \\
\hline Gemmeiza 10 x C.B. 255 & 2.617 & 4.033 & $\mathbf{3 . 3 2 5}$ \\
\hline Gemmeiza 9 & 2.510 & 3.437 & $\mathbf{2 . 9 7 3}$ \\
\hline Gemmeiza 9 X.B. 255 & 2.000 & 3.000 & $\mathbf{2 . 5 0 0}$ \\
\hline Gemmeiza 9 x C.B. 254 & 2.667 & 4.153 & $\mathbf{3 . 4 1 0}$ \\
\hline Gemmeiza 10 x C.B. 254 & 2.477 & 3.450 & $\mathbf{2 . 9 6 3}$ \\
\hline Sakha 94 & 1.847 & 3.607 & $\mathbf{2 . 7 2 7}$ \\
\hline Mean & $\mathbf{3 . 9 8 8}$ & $\mathbf{6 . 1 7 6}$ & $\mathbf{5 . 0 8 2}$ \\
\hline LSD at 5\% for: & \multicolumn{3}{|l}{} \\
Genotypes & \multicolumn{3}{|l}{} \\
Salinity & 0.473 & \\
Gen. x Salinity & & 0.673 & \\
\hline
\end{tabular}

The considerable accumulation of proline as a striking sequence and main feature of increasing water or salt stress has been previously confirmed by several workers, due to its major physiological functions under such stress 
conditions. These functions include osmoregulation; as a compatible cytoplasmic solute it apparently counteracts the osmotic potential of the vacuole salts (Bray, 2000). Higher osmolytes accumulation especially proline and soluble proteins seems to be related to salt tolerance in wheat as shown in the present investigation and not to be a consequence of tissues reaction to salt stress damage. Kholova et al., (2009) reported that, the deleterious effects of salt on plant growth of wheat may be based on the higher magnitude of total free amino acids and proline. Siddiqui et al., (2008) added that, proline and other compatible solutes are believed to cause the minimal inhibition of metabolism. Proline is organic osmolytes solute with an amphiphilic molecule protects the hydrophobic parts of protein which suffer first when water potential is lowered. The proline functions also include enzyme and memebrance protection against salt inactivation (Tajdoost et al., 2007) and as an indicator of plant resistance to stress. Chen and Murata, (2002) strongly suggested that the function and the accumulated proline and other compatible solutes that are not toxic under Nacl salinity, compatible solutes are defined as water-soluble organic compounds of a low molecular weight termed as osomprotectants. Natural osmoprotectant concentration in cytoplasmic compartments are osmotically significant because they have pivotal roles in maintaining cell turgor and the driving gradient for water uptake under stress (Rontein et al., 2002) allowing processes such as stomatal opening , photosynthesis and cell expansion (Serraj and Sinclair, 2002) . Proline did not start to accumulate in the leaves until the concentration of total monovalent cations reached a threshold of approximately $200 \mu \mathrm{mol} / \mathrm{g}$ fresh weight. In this connection, Bray (2000) reported that, in addition to the role of organic solutes accumulation on cell water relations, it may helps towards the maintenance of ionic homeostasis and of the $\mathrm{C} / \mathrm{N}$ ratio removal of free radices and stabilization of macromolecules and organelles such as proteins, protein complex and membrances. In plants, the major compatible osmoprotectant solutes are glycinebetaine and proline (Misra and Gupta, 2005), are thought to function as osmoprotectant for protein (Bohnert and Jensen, 1996). These solutes provide a protective environment for enzymes and macromolecular structure and function. The contributory role of osmoprotectants (glycinebetaine and protein) to osmotic adjustment under salt stress was confirmed in various Thus,plant species (Meloni et al., 2001). Thus, solute accumulation was considered as a suitable screening parameter for salinity tolerance.

\section{2- Total sugar:}

Data presented in Table (7) show that salinity increased total sugars in the shoots in all wheat genotypes. These results indicate a positive correlation between salinity and sugar accumulation potential with special referring to the superiority of genotype Gemmeiza 7 which greatly exceeded the other studied genotypes in their sugar concentrations particularly at the highest salinity level. In this context, Larcher (1995) reported that, glycophytes adapt themselves to some wheat saline conditions by lowering osmotic potential through converting starch to sugar. Helaly et al., (2009-a) found that, the photosynthetic activity per unit assimilating area may not be greatly altered by moderate saline level, even some enhancement might 
occurred. This may be due, partly, to increased stability of chlorophyllprotein- lipid complex in the chloroplast of plants grown under salinity (Serraj and Sinclair, 2002). Sharma et al., (1996) concluded that, sugars and proline accumulations were considered as a suitable screening parameter for chloride salinity tolerance and its mediated and concomitant through decline in protein synthesis, $\mathrm{N}$ and $\mathrm{K}$ concentrations and $\mathrm{K} / \mathrm{Na}$ ratio. Tajdoost et al., (2007) suggested that, the increment in soluble carbohydrate due to salinity may, in turn , play an important role in increasing the osmotic pressure of the cytoplasm.

Bartels and Sunkar (2005) found a strong correlation between sugar accumulation and osmotic tolerance. Hence, improvement of crop performance by increasing osmotic potential-adjusting ability might be more significant in increasing plant growth. The current hypothesis is that sugars acts as osmolytic and /or protect specific macromolecules and contribute to the stabilization of membrane structure (Hatung, 2004).

The accumulation of sugars was the result of an enhanced efficiency in the use of carbon coupled to a reduction in cellular metabolism, that could favour the accumulation of respiratory substrate to support the osmotic adjustment required to survive in saline media (Tajdoost et al., 2007). This accumulation has been attributed to an impaired carbohydrates utilization and reduced respiration rate at high salinity level. However, the significance of sugars as an adjustment is still in debate and varies according to the plant species.

Table (7): Effect of $\mathrm{NaCl}$ salinity on total sugars concentration (mg glucose/g D.Wt.) in the shoots of wheat genotype at four weeks from sowing.

\begin{tabular}{|c|c|c|c|}
\hline Salinity $(\mathrm{mg} / \mathrm{l})$ & 0 & 8000 & Mean \\
\hline Gemmeiza 7 & $74, \wedge$ & Irr, & $90, r$ \\
\hline Gemmeiza 10 x C.B. 255 & or, \& & $9 \vee, 1$ & $v_{\bullet, r}$ \\
\hline Gemmeiza 10 & $\varepsilon \vee, 1$ & $9 \vee, r$ & VY,I \\
\hline Gemmeiza 9 & $\varepsilon \vee, 0$ & $\mathrm{ov}, \mathrm{V}$ & $0 Y, T$ \\
\hline Gemmeiza 9 x C.B. 255 & 01,1 & $9 \cdot, 1$ & $v \cdot, \tau$ \\
\hline Gemmeiza 9 x C.B. 254 & $\leq 7.1$ & 10,0 & $70, \mathrm{~V}$ \\
\hline Gemmeiza 10 x C.B. 254 & $\varepsilon 0, r$ & 00,7 & $0 ., \varepsilon$ \\
\hline Sakha 94 & $\leq 9, r$ & $0 \wedge, 1$ & or,, $\mathrm{V}$ \\
\hline Mean & $0 \cdot, 1$ & $\wedge r, 1$ & 67.1 \\
\hline LSD at $5 \%$ for: & & & \\
\hline Genotypes & & 4.7 & \\
\hline Salinity & & 2.4 & \\
\hline Gen. x Salinity & & 6.7 & \\
\hline
\end{tabular}


3- $\mathrm{Na}^{+}$and $\mathrm{K}^{+}$as well as their ratio:

Table (8) shows that, sodium concentration in the roots as well as in the shoots of all studied genotypes was increased due to an increase in $\mathrm{NaCl}$ whereas, that of potassium was decreased. $\mathrm{Na}^{+} / \mathrm{K}^{+}$ratio was also increased due to the increase in $\mathrm{Na}^{+}$influx. The promotion of $\mathrm{Na}^{+}$uptake by salinity was accompanied by a corresponding decrease of $\mathrm{K}^{+}$concentration showing an apparent antagonism between $\mathrm{K}^{+}$and $\mathrm{Na}^{+}$.

It is well documented that, nutrient concentration and accumulation were adversely affected under salinity as reported by many investigators (Helaly et al., 2009-a and Gadalla, 2009). Several mechanisms may be responsible by a decline in $\mathrm{K}^{+}$concentration with increasing salinity including the antagonism of sodium at the site of uptake in roots (Hatung, 2004).

Table (8): Effect of $\mathrm{NaCl}$ salinity on $\mathrm{Na}^{+}$, and $\mathrm{K}^{+}$concentration $(\mathrm{mg} / \mathrm{g}$ dry weight) as well as $\mathrm{K}^{+} / \mathrm{Na}^{+}$ratio in the shoot of wheat genotypes at four weeks from sowing.

\begin{tabular}{|c|c|c|c|c|c|c|c|c|c|}
\hline \multirow{3}{*}{$\overbrace{\text { Genotypes }}^{\text {Treatments }}$} & \multicolumn{3}{|c|}{$\mathrm{Na}^{+}$} & \multicolumn{3}{|c|}{$\mathrm{K}^{+}$} & \multicolumn{3}{|c|}{$\mathrm{K}^{+} / \mathrm{Na}^{+}$} \\
\hline & \multicolumn{9}{|c|}{ Salinity (mg/l) } \\
\hline & 0 & 8000 & Mean & 0 & 8000 & Mean & 0 & 8000 & Mean \\
\hline Gemmeiza 7 & 2.53 & 4.60 & 3.56 & $m, 03$ & IV,ro & $r \leq, r V$ & $1 Y, \sum \lambda$ & $r, v \uparrow$ & $\Lambda, 1\}$ \\
\hline Gemmeiza 10xC.B. 255 & 3.13 & 5.36 & 4.24 & $r \leqslant, T$. & $1 \leq, 13$ & $19, \mathrm{rV}$ & $\mathrm{V}, \wedge \mathrm{T}$ & $1, \wedge \varepsilon$ & $\varepsilon, \wedge 0$ \\
\hline Gemmeiza 10 & 3.13 & 6.90 & 5.01 & 22.97 & 10,0 & 11,91 & $\begin{array}{ll}, r r \\
\end{array}$ & $r, 11$ & $\varepsilon, V_{0}$ \\
\hline Gemmeiza 9 & 3.10 & 6.87 & 4.98 & $r 1,00$ & r),r3 & $r, \leqslant r$ & $7,9 \varepsilon$ & $r, 11$ & $0, \cdot r$ \\
\hline Gemmeiza 9 x C.B. 255 & 3.33 & 7.87 & 5.60 & 24.40 & 14.33 & $19, r v$ & 7.35 & 1.82 & $\varepsilon, 0 \wedge$ \\
\hline Gemmeiza 9 x C.B. 254 & 3.20 & 8.13 & 5.66 & 21.77 & 14.57 & $1 \wedge, 1 \mathrm{~V}$ & 6.81 & 1,81 & $\varepsilon, r$. \\
\hline Gemmeiza 10xC.B. 254 & 2.83 & 8.50 & 5.66 & 21.33 & 16.50 & $1 \Lambda, 94$ & 7.56 & 1.94 & $\varepsilon, V_{0}$ \\
\hline Sakha 94 & 2.90 & 8.43 & 5.66 & 21.20 & $10, \wedge \mathrm{V}$ & 11,0r & 7.33 & $1, \wedge \Lambda$ & $\varepsilon, 7$ \\
\hline Mean & 3.02 & 7.08 & 5.05 & YT,TY & 17,12 & 19.89 & 8,97 & $r, r q$ & 5.12 \\
\hline \multicolumn{10}{|l|}{ LSD at $5 \%$ for: } \\
\hline Genotypes & \multicolumn{3}{|c|}{0.44} & \multicolumn{3}{|c|}{1.4} & \multicolumn{3}{|c|}{0.70} \\
\hline Salinity & \multicolumn{3}{|c|}{0.21} & \multicolumn{3}{|c|}{0.7} & \multicolumn{3}{|c|}{0.35} \\
\hline Gen. x Salinity & \multicolumn{3}{|c|}{0.62} & \multicolumn{3}{|c|}{2.0} & \multicolumn{3}{|c|}{1.01} \\
\hline
\end{tabular}

In addition, salinity appears to affect the distribution pattern of nutrient elements within various pant organs (Yang et al., 2003) on wheat plants. In a saline conditions, plants take up excessive amount of $\mathrm{Na}^{+}$as in halophytes resulting in high $\mathrm{Na}^{+} / \mathrm{Ca}^{++}$and lower $\mathrm{K} / \mathrm{Na}^{+}$ratios which may impair the selectivity of the root membrane (Gadalla, 2009). The increase in $\mathrm{Na}^{+}$ concentration mainly in the vacuole provides an osmotic adjustment of salt affected plants (Sakr et al., 2004). This accumulation might be due to the important role of sodium in increasing osmotic pressure which facilitate absorption of water need for plants to tolerate the harmful effect on growth caused by salinity. The hyper-accumulation of sodium has direct toxic effect, as it interferes with enzyme structure and function. It may also interfere with the function of potassium as a co-factor in various reactions. Many of the deleterious effects of $\mathrm{Na}^{+}$, however, seems to be related to the structure change observed in various membranes of salt stressed plants, and the 
plasmalemma has been shown to loose its specific permeability (Helmy, 2008). On the other hand, the increase in vacuolar sodium induced with sodium chloride was corresponded by a decrease in $\mathrm{K}^{+}$in the cytoplasm, of xylem parenchyma cells, or of the shoot (Yeo et al., 1977).

The reduction of internal potassium concentration could be related to (i) increased potassium efflux into the growth medium and inhibit transport of this ion root and up to the shoot (Cramer et al., 1989). (ii) the antagonism between $\mathrm{K}^{+}$and $\mathrm{Na}^{+}$cations, which increased considerably as salinity increased (Mozafar and Oertli, 1990). This antagonism may be due to the direct competition between sodium and potassium on the absorption sites of roots leading to a reduced level of internal $\mathrm{K}^{+}$at high external $\mathrm{Nacl}$ concentrations (Ben-Hayyin et al., 1989). (iii) excess of $\mathrm{Na}^{+}$in the root media results in a passive accumulation of this ion in the root and shoot lead to a high $\mathrm{Na}^{+} / \mathrm{K}^{+}$ratio and reduced plant growth (Helmy, 2008).

The increase in $\mathrm{Na}^{+} / \mathrm{K}^{+}$ratio noticed in the present investigation due to excessive amount of $\mathrm{Na}^{+}$and $\mathrm{Cl}^{-}$in the media may be attributed to low accumulation of $\mathrm{Na}^{+}$and $\mathrm{Cl}^{-}$in the plant organs which, in turn, impairs the selectivity of the root membrane (Misra and Gupta, 2005 and 2006).

\section{REFERENCES}

Aboshama, H.M.S. and A.E. Hegazy (2009). In vitro screening and production of salt tolerant Citrus volkamariana plant . J. Agric. Sci., Mansoura Univ. , 34(10): 10115-10133.

Bartels, D. and R. Sunkar (2005). Drought and salt tolerance in plants. CRC Crit. Rev. Plant Sci. 24:23-58.

Bates, L.S. ; R.P. Waldren and I.D. Teare (1973). Rapid determination of free proline for water-stress studied. Plant and Soil, 39: 205-207.

Ben-Hayyim, G. ; Y. Vaadia and B.G. Williams (1989). Protein associated with salt adaptation in citrus and tomato cells: Involvement of $26 \mathrm{kDa}$ polypeptides. Physiol. Plant. 77: 332-340.

Bohnert, H.J. and R.G. Jensen (1996). Strategies for engineering water stress tolerance in plants. Trends in Biotechnology 14: 89-97.

Bray, E.A. (2000). Molecular response to water deficit. Plant Physiol. 103: 1035-1040.

Chen, T.H.H. and N. Murata (2002). Enhancement of tolerance of abiotic stress by metabolic engineering of betains and other compatable solutes. Curr. Opin. Plant Biol. 5: 250-257.

Cramer, G. ; A. Lauchi and V. Polito (1989). Displacement of $\mathrm{Ca}^{++}$by $\mathrm{Na}^{+}$ from the plasmatemma of root cells. Aprimary response to salt stress. Plant Physiol., 79: 207-211.

Demir, I.; K. Mavi; M. Ozcoban and G. Okeu (2003). Effects of salt stress on germination and seedling growth in serially harvested aubergine (Solanum melongena I.) seeds during development. Israel J. of plant Sci. 51(2): 125-131. 
Esmail. H.F., (2005). Effect of some trace-elements on Zea mays, L plants under saline condition. Ph.D. Thesis, Fac. Agric., Mansoura Univ., Egypt.

Foolad, M.R.; P. Subbiah; C. Kramer and G.Y.G. Lin (2003). Genetic relationships among cold, salt and drought tolerance during seed germination in an interspecific cross of tomato. Euphytica, 130: 199206.

Gadalla, S.F. (2009). The role of antioxidants in inducing wheat flag leaf osmotic adjustment under salinity stress. J. Agric. Sci. Mansoura Univ. 34(11): 10663-10685.

Hanaa Fatouh, Y. M. (2003). Physiological studies on production of wheat plants more tolerant to salinity via modern Biotechnology. Ph.D. Thesis, Cairo Univ., Egypt

Hatung, W. (2004). Plant response to stress: Abscisic acid fluxes. Marcel Dekker Inc., New York. pp. 540-690.

Helaly, M.N.; A.A. Arafa ; R. A. Fouda and H.F. Esmail (2009-a). Response of two newly development corn genotype. (Zea mays L.) to some trace elements under salt stress throughout their growth life spane. J. Agric. Sci. Mansoura Univ. 34 (8): 9015-9036.

Helaly, M.N.; M.T. Saker; Z.E. Mohamed; A.E. Allam and M. A.Ghaly (2009b). Effect of biostimulants remidiation substances (brs) on seed germination and seedling growth of some sugar beet cultivars under stress conditions . . Agric. Sci., Mansoura Univ. , In Press.

Helmy, M.Y.I. (2008). Production of wheat plants more tolerant to abiotic stress via modern applied biotechnology techniques. Ph.D. Thesis, Cairo Univ., Egypt.

Hewitt, E.J. (1952). Sand and water culture methods used in the study of plant nutrition. Common Wealth Agric. Bweau, England, 241.

Kholova, J.; R.K. Sairam; R.C. Meana and G. C. Srivastava (2009). Response of maize genotypes to salinity stress in relation to osmolytes and metal ions contents, oxidative stress and antoxidant enzymes activity. Biol. Plant. 53 (2): 249-256.

Larcher, W. (1995). Physiological Plant Ecology. $3^{\text {rd }}$ Ed. Springer Verlag. Berlin.

Meloni, D.A.; M.A. Oliva; H.A. Ruiz and C.A. Martinez (2001). Contribution of proline and inorganic solutes to osmotic adjustment in cotton under salt stress. J. Plant Nutr. 24: 599-612.

Misra, N. and A.K. Gupta (2005). Effect of salt stress on proline metabolic in salt tolerant green gram cultivar. Plant Sci. 169: 331-339.

Misra, N. and A.K. Gupta (2006). Interactive effects of sodium and calsium on proline metabolism in salt tolerant green gram cultivar. Amer, J. Plant Physiol.1(1): 1-12.

Mozafer, A. and J.J. Oertli (1990). Multiple effects of salinity stress and temperature shock on growth of barley. Plant and Soil, 128, 5:15.

Rotein, D.; G. Basset and A.D. Hanson (2002). Metabolic engineering of osmoprotectants accumulation in plants. Metab. Engineer. 4: 49-56.

Sadasivam, S. and A. ManicKam (1996). Biochemical methods. Second Ed., New age Internat., India. 
Sadeghian, S.Y. and N. Yavari (2004). Effect of water deficit stress on germination and early seedling growth in sugar beet. J. Agronomy \& Crop Science 190, 138-144.

Sakr, M.T. ; M. El-Hadidi ; A.M. El-Kheer and S. Farouk (2004). Physiological studies of some osmoregulators on Canola. Internat. Conversation microbiology and biotechnology in Africa and Arab Region. pp. 295321.

Schmidt R.E. (2005). Biostimulants function in turfgrass nutrition. Phd emeritus virginia tech.

Serraj, R. and T. R. Sinclair (2002). Osmolyte accumulation: can it really help increase crop yield under drought condition?. Plant Cell Environ. 25: 333-341.

Sharma, P.K. ; K.S. Datta ; B. Kumar and R. Angrish (1996). Differential response of wheat to chloride and sulphate salinities at germination and early seedlings growth. Haryana Agric. Univ. J. Res. 26(1): 1-7.

Siddiqui, M.H. ; M.N. Khan; F. Mohammed and M.M. A. Khan (2008). Role of nitrogen and gibberellin $\left(\mathrm{GA}_{3}\right)$ in the regulation of enzyme activaties and in osmoprotectant accumulation in Brassica Juncea L. under salt stress. J. Agron. Crop Sci. 194: 214-224.

Smith, S.E. and A.K. Doberenz (1987). Seed age and salt tolerance at germination in Alfalfa. Crop Sci. 27, 1053-1056.

Tajdoost, S.; T. Farboodnia and R. Heidari (2007). Salt pretreatment enhance salt tolerance in Zea mays L. seedling. Pakist. T. Biol. Science . 10(12): 2086-2090.

Tugnoli, D.V. and D.G. Bettini (2001). Verifying the germinability of commercial sugar beet seeds under laboratory conditions and from emergence in the field. Proceedings of the $46^{\text {th }}$ IIRB Congress, 26-27 June, Bruges, pp. 333-340.

Tripathi, S.B.; K. Gurumurthi ; A.K. Panigahi and B.P. Shaw (2007). Salinity iduced changes in proline and betaine contents and synthesis in two aquatic macrophytes differing in salt tolerance. Biol. Plant 51: 110-115.

Visser, B. (1994). Technical aspects of drought tolerance . Biotechnol. Dev. Monit. 18, 5.

Yang, Y.L. ; J.K. Guo ; F. Zhang ; L.G. Zhao and L.X. Zhang (2003). Nacl induced changes of the $\mathrm{H}^{+}$-ATPase in root plasma membrane of two wheat cultivars. Plant Sci. , 166(4): 913-918.

Yeo, A.R. ; D.Kramer ; A. Laeuchli and J. Gullasch (1977). Ion distributionb in salt-stressed mature Zea mays roots in relation to structure and retention of sodium. J. Exp. Bot., 28: 17-29. 


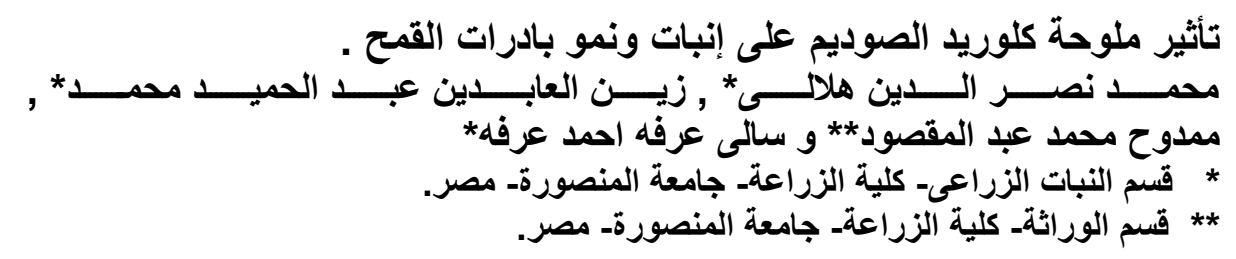

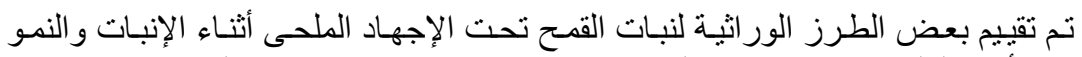

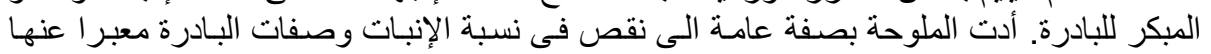

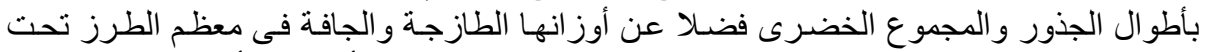

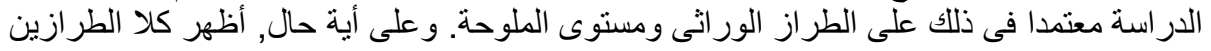

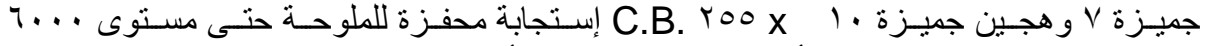

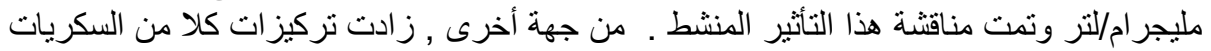

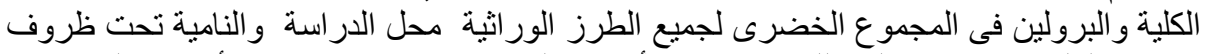

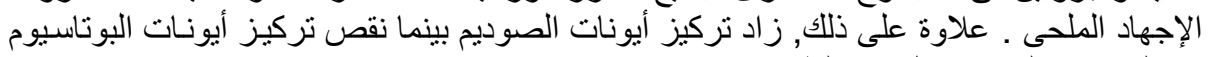

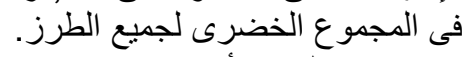

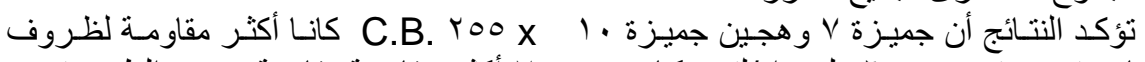

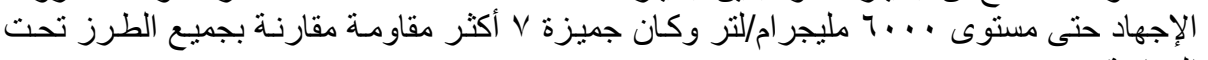

كلية الزراعه - جامعة المنصوره كلية الزراعة - جامعة المنوفية
قام بتحكيم البحث

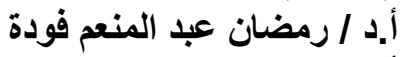

أ.د / أد / محمود إبران عيد حمن فئن 